Anne Holt har doktorgrad i fysikk fra Universitetet i Oslo, og jobber nå som førsteamanuensis ved Avdeling for lærerutdanning og naturvitenskap, Høgskolen i Hedmark. Hennes forskningsinteresse er hvordan barn lærer naturfag i skolen.

Anne Bergliot $\varnothing$ yehaug har hovedfag i fysiologi fra Universitetet i Oslo, har lang erfaring som lærer i naturfag i den videregående skolen og er nå ansatt som høgskolelektor ved Avdeling for lærerutdanning og naturvitenskap, Høgskolen i Hedmark. For tiden arbeider hun med en PhD, der hun studerer dialogene i et 'designet naturfagklasserom'.

\title{
Metode for analyse av læreplaner i naturfag - anvendt på den norske læreplanen
}

\begin{abstract}
In this paper we suggest a method for analysing curriculums in science, and we use this to investigate how the present Norwegian science curriculum prepares students for scientific informed citizenry. Science is both a body of knowledge that represents current understanding of natural systems and the process where that body of knowledge has been established and is being continually extended, refined, and revised. Both elements are truly essential, a student cannot understand science without being competent in both. Thus, there are clear recommendations about how to teach science in school, described as four strands of learning. The method analyses competence descriptions both according to the four strands and taxonomic level (depth of knowledge). The analysis shows that the Norwegian curriculum only to a certain degree correlates to recommendations about how science should be taught. Moreover, it seems like the method has potential beyond science curriculum analysis.
\end{abstract}

\section{INNLEDNING}

Læreplaner i naturfag gir føringer for hva barn og unge skal lære om naturvitenskap. Naturvitenskap er både et sett av begreper, modeller og teorier som til sammen er grunnlaget for vår nåværende forståelse, og de prosessene som denne kunnskapsbasen kontinuerlig har utviklet seg ved hjelp av. Synet på hvilke produkt- og prosesskomponenter som læreplanen bør legge vekt på kan variere. Spørsmålet er hva som er hovedhensikten med skolens naturfag.

Mange mener det overordnede formålet med faget bør være å gi alle den nødvendige kompetansen de trenger for å gjøre personlige valg og for å kunne delta i samfunnet. Vi stilles jevnlig overfor naturvitenskapelige spørsmål som har betydelige demokratiske, kulturelle og sosiale konsekvenser for oss. Det kan dreie seg om å vurdere argumenter i klimadebatten, si ja eller nei til vaksine eller ta stilling til om det skal være tillatt å ta patent på liv. Et sentralt spørsmål er hvordan skolens naturfag skal bidra til elevenes kompetanse i det å fungere optimalt som bevisste aktører i samfunnet. Altså å forme kritisk tenkende og handlende individer. Informantene 
i en nylig avsluttet PhD-studie etterlyser mer naturfaglig kompetanse og veiledning for å kunne realisere sitt ideal om å være myndige mennesker som tar selvstendige kunnskapsbaserte avgjørelser; noe de i liten grad opplever å få gjennom naturfagsundervisningen i skolen (Jónsdóttir, 2009). Kolstø (2003) hevder at hvis skolens naturfag skal kunne fungere allmenndannende i forhold til samtidskontroverser må faget tilby elevene analyseredskaper og ferdigheter som kan sette dem i stand til å foreta adekvate vurderinger med utgangspunkt i egne verdier. Naturfaget bør som alle andre skolefag legges opp slik at alle elever får utviklet en grunnleggende kunnskapsbase og sine grunnleggende ferdigheter, interesser og måter å tenke på, uavhengig av om de senere i livet velger naturvitenskapelige yrker eller ikke (se for eksempel Duschl, Schweingruber, \& Shouse, 2007: s. 34; Sjøberg, 2009).

Det er behov for et analyseverktøy for å kunne vurdere læreplaner i naturfag. I denne artikkelen foreslår vi en metode for dette. Vi har undersøkt hvordan dette analyseverktøyet fanger ulike aspekter ved det å beherske naturfag (bredde og dybde) ved å teste det ut på den norske læreplanen i naturfag (Utdanningsdirektoratet, 2006). Dette bidraget blir da samtidig en analyse av hvordan ulike aspekter ved det å beherske naturfag blir ivaretatt i den norske læreplanen i naturfag. Denne læreplananalysen føyer seg således inn som et bidrag til den diskusjonen som Kolstø (2009) har innledet med sin analyse av den norske læreplanen i naturfag.

\section{PÅ HVILKEN MÅTE BøR ELEVENE LAERE NATURFAG I SKOLEN?}

Når man skal utvikle en metode for å analysere læreplaner i naturfag, må man ta stilling til hva slags kompetanse man ønsker at elever skal oppnå gjennom det faget som læreplanen gjelder for. Analyseverktøyet må kunne fange alle aspekter ved det å beherske faget. Derfor innledes denne artikkelen med en grundig redegjørelse for hva det innebærer å beherske naturfag (de fire læringstrådene), før selve metoden for å analysere læreplaner i naturfag presenteres.

Tradisjonelt har både læreplaner og lærebøker for naturfag skilt tydelig mellom naturvitenskapelig produkt og prosess. I takt med ideologiske svingninger i samfunnet har hovedvekten vekslet, mellom de to ytterpunktene produkt og prosess (Sjøberg, 2009). Når faget presenteres som et sett med etablerte produkter i form av faktakunnskap uten at disse settes i sammenheng med eksperimenter, observasjoner eller med rom for tolkning, viser det seg å ha begrenset appell (Europakommisjonen, 2004). I hele Europa etterspørres en fornying av skolefaget naturfag, der prosess får en mer sentral plass. En nyorientering som man har stor tiltro til er 'scientific inquiry' (Europakommisjonen, 2007). Det norske svaret på 'scientific inquiry' kommer til uttrykk gjennom et eget hovedområde i naturfagplanen, kalt Forskerspiren (Utdanningsdirektoratet, 2006).

Duchl m.fl. (2007) tar nettopp hensyn til at det finnes forskjellige perspektiver på hva naturvitenskap er, og er opptatt av hvilke konsekvenser dette bør ha for naturfag som skolefag. De er spesielt opptatt av naturvitenskap som prosess, og sidestiller tre ulike prosessperspektiver som gjensidig utfyller hverandre:

- Naturvitenskap som en prosess for logisk resonnering om evidens

- Naturvitenskap som en prosess der teorier er i forandring

- Naturvitenskap som en prosess for deltagelse i en kultur der vitenskap blir praktisert

Duschl m.fl. understreker at det å beherske naturvitenskap er mangfoldig og sammensatt, og at det å beherske ett aspekt ved naturvitenskapen er nært knyttet sammen med beherskelse av de andre. De fire neste avsnittene omhandler på hvilken måte produkt- og prosessperspektivene på naturvitenskap er viktige for at elevene i skolen skal kunne utvikle en optimal og helhetlig naturfaglig kompetanse. 


\section{Forstå, bruke og tolke naturvitenskapelige forklaringer (Læringstråd 1)}

Skolefaget naturfag består av og bør fortsatt bestå av et sett av begreper, modeller og teorier, altså etablert kunnskap i naturvitenskapen. Et sentralt spørsmål er hvilke begreper, modeller og teorier som det er viktig at elever lærer. Læreplaner blir ofte kritisert for å dekke for mange temaer, og at alle disse temaene framstilles sidestilte og likeverdige (Duschl m.fl., 2007). Men det handler ikke bare om å lære separate begreper, modeller og teorier, men også om å kunne integrere og bruke disse i nye og komplekse sammenhenger. Læring og anvendelse av begreper, modeller og teorier omfatter naturfag som produkt.

\section{Produsere og vurdere naturvitenskapelige forklaringer og evidens (Læringstråd 2)}

Elevers forståelse og forestillinger om begreper, modeller og teorier viser seg å ha stor betydning for sentrale prosessperspektiver som å generere hypoteser (Echevarria, 2003; Klahr, Fay, \& Dunbar, 1993; Penner \& Klahr, 1996; Schauble, 1990, 1996; Zimmerman, Raghavan, \& Sartoris, 2003), designe eksperimenter (Kuhn, Garcia-Mila, Zohar, \& Andersen, 1995) og vurdere evidens (Amsel \& Brock, 1996; Koslowski, 1996). Kompetansen som kreves dreier seg på den ene siden om kunnskap om verden generelt og om emnepesifikk kunnskap spesielt, og på den andre siden om forståelse av hensikten med vitenskapelige undersøkelser og formålet med naturvitenskap i en videre forstand. I utforskende arbeid er derfor resonneringsprosesser og begrepsforståelse gjensidig avhengig av hverandre (Lehrer, Schauble, Strom, \& Pligge, 2001; Schauble, 1996). Elever trenger å lære å koordinere tidligere kunnskaper og ny evidens fra egne undersøkelser (Duschl m.fl., 2007). Det er også viktig at de utvikler ferdigheter i å designe eksperimenter, samle og behandle data og gjøre modelleringer. For å sikre at elevene får denne nødvendige erfaringen, må slike prosesser gjenspeiles i læreplanen i naturfag. Det vil si en læreplan som vektlegger det å forstå, bruke og tolke naturvitenskapelige forklaringer (produkt) og produsere naturvitenskapelig evidens (prosess), samt koblingen mellom disse.

\section{Reflektere over hvordan naturvitenskapelig kunnskap utvikles (Læringstråd 3)}

Det blir hevdet at borgere som forstår hvordan naturvitenskap blir til, vil være mer bevisste i forhold til vitenskapelige argumenter i sammenhenger som har allmenninteresse: for eksempel globale klimatrusler, genmodifisert mat, alternativ medisin (Duschl m.fl., 2007 :s. 169). Kolstø (2003) slutter at norsk skole ikke forbereder elevene til en slik bevissthet:

De prosesser som avgjør hvilke resultat fra forskningsfronten som skal bli regnet som pålitelige ser det ut til at elevene forblir ukjente med selv etter 13 år med naturfag i skolen. Situasjonen er derfor den at skolens naturfag ikke forbereder elevene til å forstå den naturvitenskap og den debatt som de møter i samfunnet ellers.

I følge Osborne m.fl. (2003) er det sjelden at man i læreplaner finner et syn på naturvitenskap som en kompleks vekselvirkning mellom vitenskapelige modeller og teorier, empiriske observasjoner av den virkelige verden og de tilhørende forutsigelser. Med tanke på skolens læreplaner, har Osborne m.fl. derfor fremmet forslag om hva som bør inngå som 'ideer om naturvitenskap'. Sandoval (2005) har på bakgrunn av denne og andres definisjoner av naturvitenskapens epistemologi (Driver, Leach, Millar, \& Scott, 1996; Lederman, Abd-el-Khalick, Bell, \& Schwartz, 2002; McComas \& Olson, 1998) foreslått å samle dette i fire nokså vide punkter:

1. Naturvitenskapelig kunnskap må betraktes som konstruert

2. Naturvitenskapelige metoder kan arte seg svært forskjellige - avhengig av hva som skal undersøkes

3. Naturvitenskapelig kunnskap er av forskjellige typer (teorier, lover, hypoteser)

4. Kunnskapen vi har i naturvitenskapen kan være mer eller mindre sikker.

Det er mye som tyder på at det er en sammenheng mellom elevers kjennskap til disse aspektene ved den naturvitenskapelige epistemologi og deres forståelse av og evne til å anvende naturvi- 
tenskapelig kunnskap. Et eksempel er, når elevene forstår at argumentasjon er et sentralt trekk ved naturvitenskapen, så vil dette ha positiv effekt på bevisstheten om egen læring og hvordan de anvender undersøkende strategier (Sandoval \& Reiser, 2004; Toth, Suthers, \& Lesgold, 2002). Beeth og Hewson (1999) studerte en lærer som lot elevene arbeide på en systematisk utforskende måte med naturfaglige fenomener og naturvitenskapens epistemologi. Læringssituasjonen lignet $\mathrm{i}$ stor grad den som kjennetegner vitenskapelige miljøer. De fant at elevene utviklet en metakognitiv bevissthet som var langt høyere enn det som man vanligvis forventer for den gitte aldersgruppen. Videre har Songer og Linn (1991) analysert effekten av et dynamisk versus et statisk syn på naturvitenskap og funnet at det dynamiske synet fører til en mer integrert kunnskap. Det er også funnet sammenheng mellom hvor sofistikert epistemologi studenter har og deres evne til å overføre kunnskap til nye områder på bakgrunn av en tekst (Gobert \& Discenna, 1997; Gobert \& Pallant, 2001). Det kan altså se ut til at det er viktig at elevene reflekterer over hvordan naturvitenskaplig kunnskap dannes. I tillegg kan det tyde på at elevene også bør reflektere over egen kunnskapsstatus og hvordan egen kunnskap utvikler seg over tid. Hvis elevene har evne til å reflektere over hvordan naturvitenskapelig kunnskap utvikles (prosess) så styrker det deres evne til å bruke kunnskapen i nye sammenhenger (produkt) og til å anvende undersøkende strategier i naturfag (prosess).

\section{Delta produktivt i naturvitenskapelig praksis og diskurs (Læringstråd 4)}

Elevers måte å lære naturfag på kan på mange vis sammenlignes med den måten som naturvitere utvikler erkjennelse på. Ved hjelp av kunnskap og språk stiller de spørsmål og skaper meningsfulle bilder av hvordan verden er. Som i vitenskapssamfunnet bør elevene også utvikle og utfordre forståelsen sin ved å overtale andre. Gjennom gruppeprosesser vil elevene kunne dele og utvikle sin forståelse av, men også sitt forhold til naturvitenskap (Brown, Collins, \& Duguid, 1989; Latour, 1990; Lave \& Wenger, 1991). Argumentasjon med den hensikten å overtale kolleger om gyldigheten av egne og andres ideer er en meget sentral del av den naturvitenskapelige praksisen (Bazerman, 1988). En metode der argumentasjon ble gjort til et eksplisitt mål allerede fra første trinn, har vist seg å være svært fruktbar (Henessey, 2002). Å skape gode argumenterende klasseromsdialoger krever at lærer både har gode kunnskaper om elevene, om faget og om diskursprosedyrer.

Spesialiserte aktiviteter som naturvitenskap krever gjerne også et spesialisert språk. Dette språket er forskjellig fra det hverdagsspråket som barn bruker. Et naturvitenskapelig språk har en tendens til å fremheve den passive stemmen, spesielt i skriftlig form. Resultatet er at leseren sjelden møter mennesker i naturvitenskapen, verken som aktør eller som deltager (Lemke, 1990). I det naturvitenskapelige språket er det stor forkjærlighet for nominaliseringer, det vil si at et verb eller et annet ikke-substantiv gjøres om til et substantiv. Slike eksempler er verbene stråle, bryte og reflektere som er gjort om til substantivene stråling, brytning og refleksjon (Kolstø, 2009; Martin, 1993). En annen utfordring elevene møter i naturfag er at tekniske termer har annen betydning enn det de kjenner fra dagligspråket (for eksempel kraft og energi) (Martin, 1993). Dette innebærer spesielle utfordringer i læring av naturfag.

Mortimer og Scott (2003) er opptatt av hvordan læreren tilrettelegger for læring gjennom klasseromssamtalene i naturfagtimene. De identifiserer en sammenheng mellom lærers hensikt med og tilnærming til samtalen og diskursens struktur. Gjennom måten læreren tilrettelegger dialogene på, kan de støtte elevene i å utvikle egne synspunkter basert på naturvitenskapelig kunnskap og evidens. Dette er i tråd med normene som gjelder i naturvitenskapen, og mange vil hevde at de samme eller liknende normer bør gjelde i skolens naturfag.

Å mestre språket, den måten å resonnere på og de normene som gjelder i naturfaget kan være en stor utfordring for alle elever. Det hevdes at å framheve og tydeliggjøre de normene og mønstrene som gjelder i naturfagklasserommet vil gi bedre muligheter for alle til å 'knekke' fagets normer (Lee \& Fradd, 1996, 1998; Lucas, Broderick, Lehrer, \& Bohanan, 2005). Det er viktig å være bevisst hva som er likt og hva som er forskjellig fra de normene som gjelder i naturvitenskapen. 
Dette gjelder spesielt måten elever tenker, snakker og bruker vitenskapelig verktøy i klasserommet (Rosebery, Warren, \& Conant, 1992).

I følge Engle og Conant (2002) kjennetegnes klasserom som lykkes i å skape 'produktiv faglig deltagelse' av at det er en sammenheng mellom hva elevene gjør og hva som er de sosiale og kognitive normene for den aktuelle fagdisiplinen. En forutsetning er imidlertid at elevene faktisk også gjør faglig fremgang innenfor den produktivt deltagende klasseromssettingen. Altså at det ikke skjer aktivitet bare for aktivitetens egen skyld, men at målet er læring både av sosiale normer, kunnskaper og ferdigheter. I naturfag vil dette for eksempel kunne være faglig fremgang i å utføre undersøkelser, fremføre komplekse argumenter, bruke gjennomførte undersøkelser til å stille nye spørsmål eller til å gjøre nye undersøkelser. Altså situasjoner der produkt- og prosessperspektivene er nært knyttet sammen.

\section{De fire læringstrådene}

Forskningsresultatene oppsummert over viser altså betydningen av at elevene lærer å arbeide på lignende måter som i forskersamfunnet, og at det å ha kompetanse i naturvitenskap er mangfoldig og sammensatt. Det å beherske ett aspekt ved naturvitenskapen er nært knyttet sammen med beherskelse av andre deler. For eksempel er evnen til å vurdere naturvitenskapelig evidens helt avhengig av at man har gode fagkunnskaper om temaet. I tillegg bør man ha kunnskaper om hvordan evidensen har framkommet og i hvilken grad den er til å stole på.

Produkt- og prosessperspektivene som er beskrevet over kan oppsummes gjennom metaforen 'de fire læringstrådene' (Duschl m.fl., 2007):

Læringstråd 1: Forstå, bruke og tolke naturvitenskapelige forklaringer

Læringstråd 2: Produsere og vurdere naturvitenskapelige forklaringer og evidens

Læringstråd 3: Reflektere over hvordan naturvitenskapelig kunnskap utvikles

Læringstråd 4: Delta produktivt i naturvitenskapelig praksis og diskurs

Det trekkes paralleller mellom disse fire læringstrådene og de enkelte trådene som er tvunnet sammen og former et tau; som enkelttrådene i et tau er trådene, som til sammen utgjør det å ha kompetanse i naturvitenskap, viklet sammen. Hver tråd støtter de andre. Med andre ord vil framgang i én tråd støtte framgang i de andre. For at elevene skal ha kompetanse i naturfag i vid og dyp forstand, anbefaler Duschl m.fl. (2007) at naturfag som skolefag legges opp slik at alle de fire læringstrådene flettes sammen. De anbefaler at de fire læringstrådene løftes fram som læringsmål for elevene, samtidig som de også danner den overordnede rammen for tenkning om og utvikling av læreplaner i naturfag. Dette innebærer en utvidelse av kompetansebegrepet i naturfag. Et sentralt spørsmål er da hva som man legger i selve kompetansebegrepet.

\section{Kompetansebegrepet}

Å komme fram til en entydig definisjon av kompetansebegrepet ser ut til å være en utfordring. Derfor blir det nå i høyere utdanning i stedet brukt begrepet loeringsutbytte når man skal beskrive hva studentene er forventet å skulle gjøre, forstå og demonstrere ved avslutningen av en modul eller et studieprogram (Adam, 2004; Kennedy, Hyland, \& Ryan, 2007). Også i de plandokumentene som la grunnlaget for Kunnskapsløftet og det endelige læreplanverket mangler det entydighet i bruken av kompetansebegrepet (Engelsen, 2008). I tillegg er ordene kompetanse og kunnskap brukt om hverandre, uten at det skilles mellom dem. Engelsen påpeker at dette blir en premiss for den forståelsen av begrepet kompetanse som kan leses ut av læreplanverket. Videre stiller hun spørsmål ved om det kun dreier seg om en "ideologisk refrasering".

Stortingsmelding 30 (2003-2004) forsøker med forankring i OECD-prosjektet - DeSeCo (DEfinition and SElection of COmpetence) å definere kompetansebegrepet på en mer presis måte. Begrepet blir her beskrevet som "evnen til å mestre en kompleks utfordring eller utføre en kompleks aktivitet eller oppgave”. Kompetanse er i DeSeCo (Rychen \& Salganic, 2001) knyttet til situasjon, og 
kompetansebegrepet er fundert på et læringssyn som knytter teori og praksis tett sammen (Knain, 2005a). Ved at de fire læringstrådene utfordrer det tradisjonelle skillet mellom produkt og prosess, beskriver de nettopp mestring av komplekse utfordringer og det å utføre komplekse aktiviteter og oppgaver. I den videre diskusjonen velger vi å forstå kompetanse på denne måten, og i tråd med definisjonen i Stortingsmelding 30 (2003-2004).

\section{METODE FOR LAEREPLNANALYSE}

Metoden for læreplananalyse som presenteres i denne artikkelen kan bare anvendes når målformuleringene er uttrykt i form av verb som eksplisitt sier hva elevene skal kunne demonstrere av kompetanse. Den norske læreplanen i naturfag, som vil fungere som en testcase, består nettopp av såkalte kompetansemål der verbene er sentrale for å beskrive kompetansen som det forventes at elevene skal ha ved endt opplæring. Kompetansemålene i den norske læreplanen i naturfag er ofte sammensatte og beskriver flere kompetanser. Et av kompetansemålene etter 7. trinn, under hovedområdet Forskerspiren, sier at "[...] eleven skal kunne formulere spørsmål om noe han eller hun lurer på, lage en plan for å undersøke en selvformulert hypotese, gjennomføre undersøkelsen og samtale om resultatet”. Her er et eksempel på hvordan det i ett og samme kompetansemål beskrives fire forskjellige kompetanser.

Når man skal vurdere nivået på den kunnskapen eller psykomotoriske ferdigheten som beskrives $\mathrm{i}$ et kompetansemål, er det ikke tilstrekkelig å utelukkende studere verbene. Verbene er ikke alltid entydige. Det har betydning hvilken kontekst verbet står i. Konteksten indikerer dybden og kompleksiteten på de kognitive prosessene som finner sted. Verb som å forklare, beskrive og tolke er eksempler på dette. Å "[...] forklare hovedtrekkene i evolusjonsteorien og grunnlaget for denne teorien" (Mangfoldet i naturen, etter 10. trinn) krever kunnskap av en annen dybde og kompleksitet enn å "[...] forklare funksjonene til de ulike plantedelene (mangfoldet i naturen, etter 7. trinn). Norman Webbs Depth-of-Knowledgemodell (DOK) tar nettopp hensyn til konteksten og kompleksiteten til aktiviteten og/eller tankeprosessen som beskrives (Webb, 1997, 2002). Derfor vil DOK være en måte å analysere kompetansemål på som er mer nyansert enn for eksempel Blooms taksonomiske modell (Bloom, 1956), og videreutviklinger av denne (Anderson, 2001), hvor nivåinndelingen først og fremst gjøres på bakgrunn av verbet. Under følger en kort redegjørelse for hvordan kompetansebeskrivelser kan inndeles etter DOK-nivå:

Nivå 1(Gjenkjennelse og reproduksjon) krever gjengivelse av informasjon, slik som fakta, definisjoner og enkle prosedyrer, for eksempel "[...] eleven skal kunne gjøre rede for begrepene fart og akselerasjon, måle størrelsene med enkle hjelpemidler [...]" (Fenomener og stoffer, etter 10. trinn). Verb som å identifisere, gjenkjenne, bruke, beregne og måle svarer til kognitive utfordringer på dette laveste nivået.

Nivå 2 (Begrepsforståelse og ferdigheter) krever mentale prosesser som går utover gjenkjennelse og reproduksjon. Fagkunnskapene eller prosessene involvert er mer komplekse og krever at den lærende gjør noen valg for hvordan han vil løse oppgaven, for eksempel "[...] eleven skal kunne innhente og systematisere data" (Forskerspiren, etter 4. trinn). Her kreves gjerne mer enn ett steg og nivået kjennetegnes ved verb som å klassifisere, organisere, anslå, gjøre observasjoner og samle, representere og sammenlikne data.

Nivå 3 (Strategisk tenkning) krever at det brukes resonnering, planlegging og evidens for å komme fram til dyp kunnskap. Det dreier seg om prosesser som å trekke konklusjoner på bakgrunn av observasjoner, bruke evidens til å underbygge logiske argumenter og forklare fenomener ved hjelp av begreper og prinsipper. Et eksempel på kompetansebeskrivelse på nivå 3 i læreplanen i naturfag er: "[...] eleven skal kunne undersøke [...] faktorer som påvirker frøspiring og vekst hos planter" (Mangfoldet i naturen, etter 7. trinn).

Nivå 4 (Sammensatt tenkning) krever at eleven kan anvende et sett av kunnskaper og ferdigheter både innenfor og på tvers av fagtemaer. Oppgaver på dette nivået krever at eleven vurderer og 
velger én løsning blant flere alternative løsninger, som for eksempel "[...] eleven skal kunne ut fra kravspesifikasjoner utvikle produkter som gjør bruk av elektronikk" (Teknologi og design, etter 10. trinn). På dette nivået kreves det videre at eleven kan føre komplekse resonnementer og planlegge komplekse forsøksdesign, som å gjennomføre en vitenskapelig undersøkelse der hun må ta hensyn til et stort antall variable.

Læreplananalysen går ut på å identifisere hver enkelt kompetanse som beskrives i hver eneste målbeskrivelse og sortere og framstille resultatene i to dimensjoner: bredde og dybde.

\section{Bredde}

Kompetansene identifisert i kompetansemålene sorteres i fire kategorier som er valgt på basis av de fire læringstrådene.

- Formidling

- Naturvitenskapelig arbeidsmåte

- Naturvitenskapelig tenkemåte

- Samhandling

Alle kompetansebeskrivelser kan plasseres inn i én av disse fire kategoriene. For å kategoriseres som Samhandling må kompetansen beskrive en prosess som krever en samhandling. Eksempler er samtale om og diskutere. Denne kategorien skal representere Læringstråd 4. Alle andre kompetansebeskrivelser, der formidling av kunnskap står sentralt, men der det ikke eksplisitt kreves en samhandling, koder vi som Formidling. Eksempler er gi eksempler på, beskrive og forklare. Slike kompetansebeskrivelser dreier seg hovedsakelig om redegjørelse for eller anvendelse av begreper, modeller og teorier i naturvitenskapen. Kategorien Formidling skal altså representere Læringstråd 1. På tilsvarende måte er kompetansebeskrivelser som dreier om den naturvitenskaplige arbeidsmåte plassert i kategorien Naturvitenskaplig arbeidsmåte, og skal representere Læringstråd 2. Til slutt er kompetansebeskrivelser som tydelig dreier som om den naturvitenskaplige tenkemåte og om hvordan naturvitenskaplig kunnskap dannes, plassert i kategorien Naturvitenskaplig tenkemåte. Denne kategorien skal derfor representere Læringstråd 3.

Det er imidlertid viktig å være klar over at enkelte kompetansebeskrivelser kan inneholde elementer ikke bare fra én kategori, men fra to eller flere. I disse tilfellene har vi kategorisert ut fra det som er hovedinnholdet i kompetansebeskrivelsen.

\section{Dybde}

Det er nødvendig å tilegne seg dyp forståelse i naturfag for å kunne se sammenhenger mellom begreper, modeller og teorier og anvende naturvitenskaplig kunnskap på nye problemstillinger. Det samme gjelder evnen til å vurdere evidens. I tillegg vil kunnskap i naturfag kunne påvirke deltagelse i naturvitenskaplige diskusjoner. Har man en overfladisk forståelse av naturvitenskaplige problemstillinger vil man sannsynligvis ha problemer med å produsere gode argumenter. På bakgrunn av dette blir kompetansebeskrivelsene analysert i henhold til dybdenivåkategorier (DOKnivå). DOK-nivået angis på en firedelt skala (DOK1 - DOK4), der DOK4 beskriver de dypeste og mest komplekse kognitive og psykomotoriske prosessene. Enkelte kompetansebeskrivelser kan vanskelig plasseres $\mathrm{i}$ ett bestemt nivå fordi det vil avhenge av hvordan de tolkes. Derfor har vi i tillegg innført kategoriene DOK1/DOK2, DOK2/DOK3 og DOK3/DOK4. Eksempler på slike typer kompetansebeskrivelser er gjennomføre undersøkelser og giøre forsøk. Tolkningsutfordringen ligger her i at dette kan gjøres med forskjellig dybde og kompleksitet. Undersøkelser og forsøk kan gjennomføres etter gitte oppskrifter/prosedyrer eller med større grad av selvstendighet. Vi har laget en ekstra kategori der vi har samlet kompetansebeskrivelser som er problematiske å plassere i et DOK-skjema. De er problematiske å plassere fordi kompetansebeskrivelsene er upresise. Disse er samtale om resultatene, diskutere, stille spørsmål, filosofere, delta og bruke sansene. 


\section{Registrering av kompetansebeskrivelser}

Kun kompetansebeskrivelser knyttet til eksplisitte verb blir talt. Det vil si at når et verb står foran en oppramsing som i "[...] eleven skal kunne beskrive sentrale egenskaper ved gasser, væsker og faste stoffer og faseoverganger ved hjelp av partikkelmodellen" (Fenomener og stoffer, etter 7. trinn), teller kompetansebeskrivelsen kun én gang. Vi mener dette blir en mer ryddig måte å framstille dataene på, enn for eksempel å telle de implisitte verbene i parentes, slik Kolstø (2009) har gjort i sin læreplananalyse.

En svakhet ved vår måte å telle på, er at det ikke kommer fram at forskjellige kompetansebeskrivelser kan ha forskjellig vekt. Å oppnå den kompetansen som beskrives i kompetansemålet "[...] eleven skal kunne planlegge og gjennomføre undersøkelser for å teste holdbarheten til egne hypoteser og velge publiseringsmåte" (Forskerspiren, etter 10. trinn), krever omfattende og systematisk arbeid over tid. Til sammenligning kan elevene oppnå kompetansen beskrevet i kompetansemålet "[...] eleven skal kunne gi eksempler på folkemedisin, blant annet den samiske, og samtale om forskjellen på alternativ medisin og skolemedisin" (Kropp og helse, etter 10. trinn), i løpet av kort tid og uten store anstrengelser. På den annen side er læreplanen i naturfag bygd opp slik at noen av de kompetansebeskrivelsene som på et generelt grunnlag forekommer i hovedområdet Forskerspiren, gjentas under de andre hovedområdene. Kompetansebeskrivelsene er da spesifisert i forhold til konkret faglig innhold. For eksempel sier et kompetansemål under hovedområdet Forserspiren etter 7. trinn at elevene på et generelt grunnlag skal kunne " [...] gjennomføre undersøkelsen og samtale om resultatet ". Samtidig er det en rekke kompetansemål under de andre hovedområdene som har formuleringer av typen "[...] eleven skal kunne gjennomføre forsøk med magnetisme og elektrisitet, beskrive og forklare resultatene" (Fenomener og stoffer, etter 7. trinn). Således kan man si at det til en viss grad blir kompensert for at de forskjellige kompetansebeskrivelsene har forskjellig vekt.

\section{MetOden ANVENDT PÅ DEN NORSKE LAREPLANEN I NATURFAG}

På bakgrunn av kategoriseringen over presenteres resultatene fra læreplananalysen fortløpende.

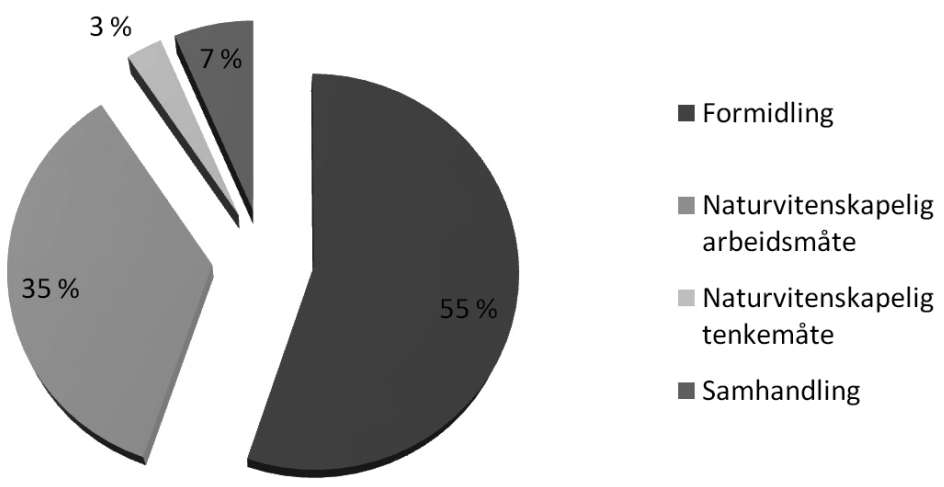

Figur 1. Vektingen av de fire kompetanseområdene formidling, naturvitenskapelig arbeidsmåte, naturvitenskapelig tenkemåte og samhandling i loereplanen for naturfag. 


\section{Anne Holt og Anne Bergliot Øyehaug}

Kakediagrammet i Figur 1 viser vektingen av de fire breddekategoriene Formidling, Naturvitenskapelig arbeidsmåte, Naturvitenskapelig tenkemåte og Samhandling i læreplanen i naturfag. Mer enn halvparten (55\%) av kompetansebeskrivelsene dreier seg om å formidle naturvitenskapelig kunnskap. Videre dreier drøyt en tredjedel (35\%) av kompetansebeskrivelsene som seg om den naturvitenskapelige arbeidsmåte. Bare 7\% av kompetansebeskrivelsene kan knyttes eksplisitt til samhandling og kun 3\% til den naturvitenskapelige tenkemåte.

Av stolpediagrammet i Figur 2 kommer det fram i hvilken grad de forskjellige breddekategoriene er representert i læreplanens seks hovedområder.

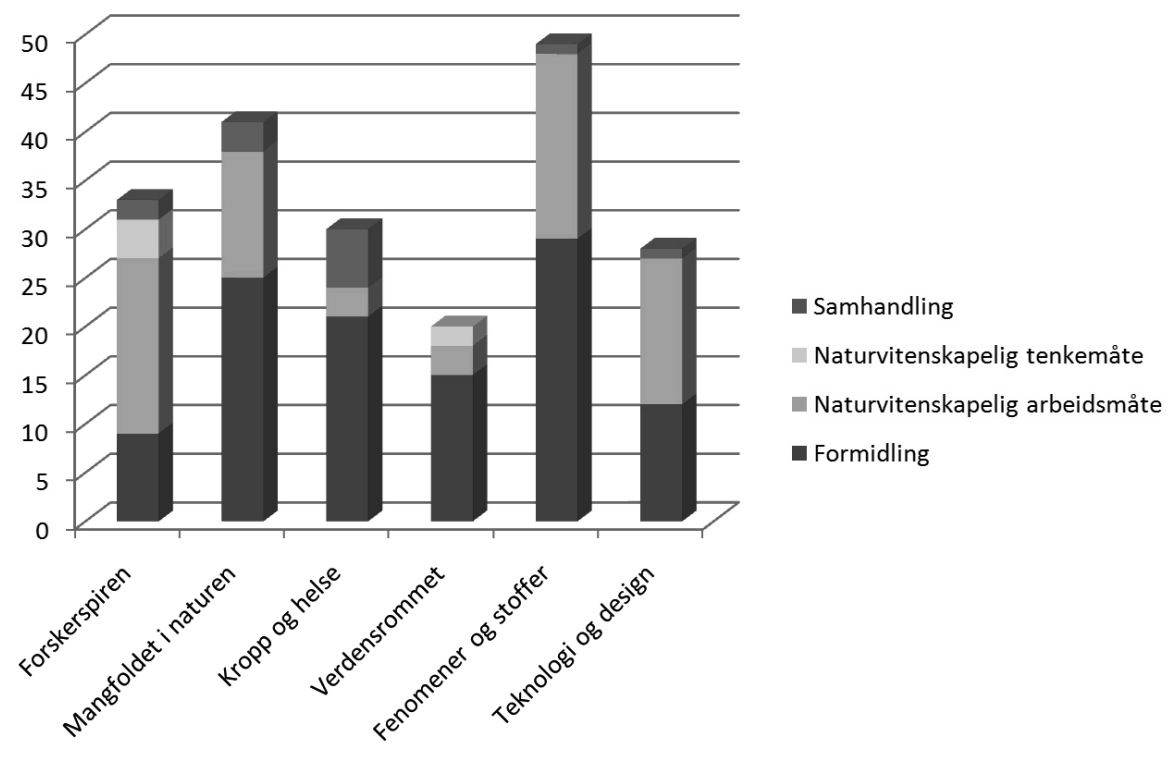

Figur 2. Vektingen av de fire kompetanseområdene formidling, naturvitenskapelig arbeidsmåte, naturvitenskapelig tenkemåte og samhandling innenfor hvert hovedområde.

Kompetansen formidling (av begreper, modeller og teorier) er representert i alle hovedområdene. Innslaget av naturvitenskapelig arbeidsmåte varierer derimot sterkt fra hovedområde til hovedområde. Kompetansebeskrivelsene i hovedområdene Kropp og helse og Verdensrommet skiller seg ut ved at det i liten grad legges opp til den naturvitenskapelige arbeidsmåte. Innenfor disse to hovedområdene skal elevene i hovedsak demonstrere formidlingskompetanse av begreper, modeller og teorier. 

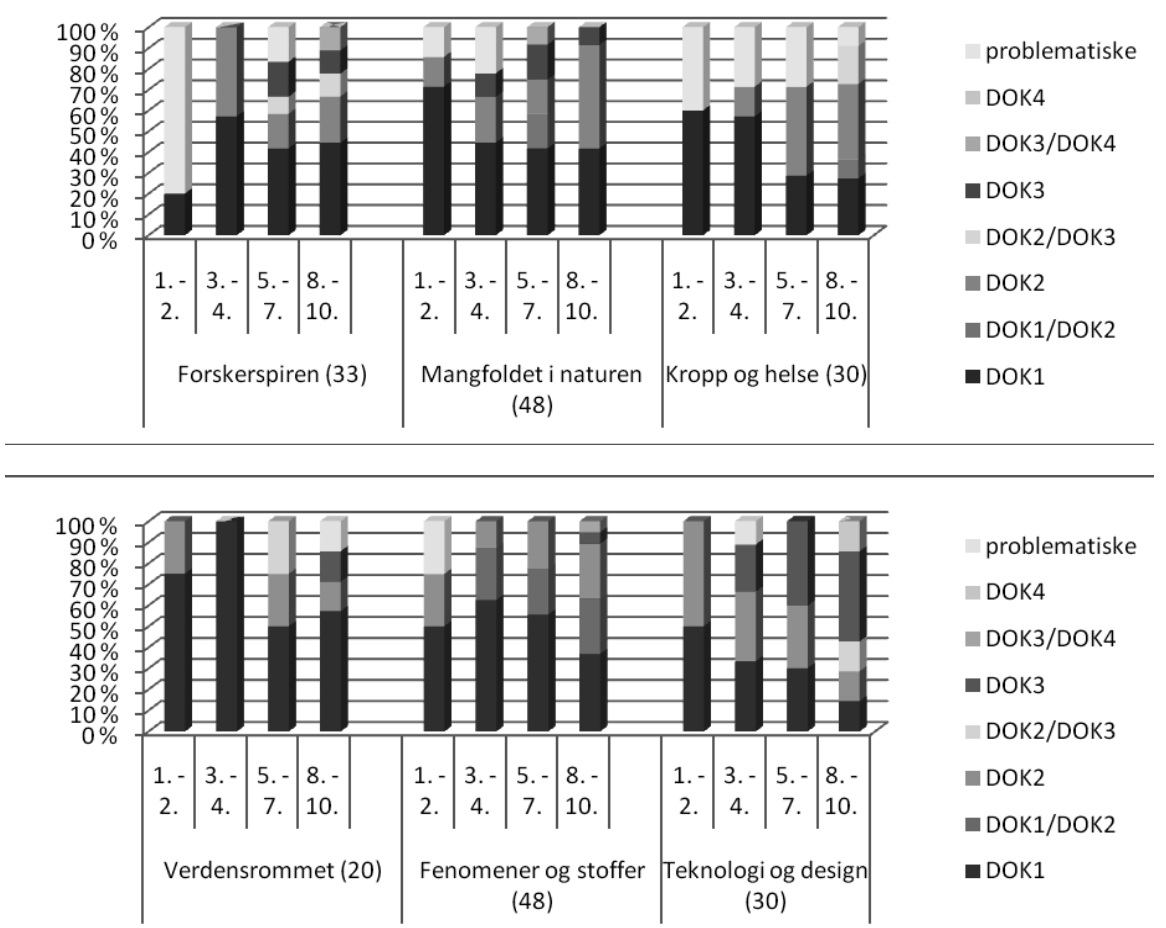

Figur 3. Kompetansebeskrivelsenes DOK-nivå innenfor hvert hovedområde og etter årstrinn.

Figur 3 viser kompetansebeskrivelsenes dybde og kompleksitet (DOK-nivå), for hvert hovedområde og etter årstrinn. Med unntak av hovedområdet Verdensrommet er det en utvikling i kompetansebeskrivelsenes dybde og kompleksitet med økende alderstrinn, dog i noe varierende grad. Hovedområdet Verdensrommet skiller seg ut ved at det er en større andel kompetansebeskrivelser på DOK1-nivå etter 4. trinn enn etter 2. trinn, og likeledes etter 10. trinn enn etter 7. trinn.

I Kropp og helse er det svært liten utvikling i DOK-nivå med økende alderstrinn. Det er ingen kompetansebeskrivelser som entydig befinner seg så høyt som på DOK3-nivå.

Innenfor hovedområdet Teknologi og design er det derimot en markert utvikling gjennom utdanningsløpet mot større dybde og kompleksitet (høyere DOK-nivå). Her fordeler kompetansebeskrivelsene seg etter 2. trinn jevnt mellom DOK1 og DOK2. Etter 4. trinn er det en tredeling mellom DOK1, DOK2 og DOK3. Etter 7. trinn krymper andelen DOK1 og DOK2 til fordel for DOK3 som nå utgjør den største gruppen (ca 40\%). Etter 10. trinn er alle fire DOK-nivåene representert, og DOK3 og DOK4 dominerer.

\section{Diskusjon}

Hensikten med denne artikkelen er å undersøke hvordan en metode for å analyse læreplaner kan fange ulike aspekter ved det å beherske naturfag (i bredde og dybde). Dette gjøres ved å teste analyseverktøyet på den norske læreplanen i naturfag. I de neste avsnittene diskuteres resultatene fra analysen, samt hvordan verktøyet er egnet til å representere både bredde- og dybdeaspektene ved det å beherske naturfag. 


\section{Bredde i naturfaglig kompetanse}

I det følgende diskuteres resultatene fra analysen opp mot Duschl m. fl. (2007) sine anbefalinger om de fire læringstråder i naturfagundervisningen. De argumenterer sterkt for at de fire læringstrådene bør være sterkt integrerte, nærmest flettet sammen som i et tau. Imidlertid isoleres læringstrådene i analysen. Dette gjøres for å få et bilde av forholdet mellom de ulike læringstrådene. Et problem man bør være oppmerksom på i den forbindelse er at man i kategoriseringsfasen derfor kan miste enkelte aspekter ved kompetansebeskrivelsene. Enkelte kompetansebeskrivelser kan inneholde elementer fra flere enn én kategori. I disse tilfellene er det som nevnt i metodedelen viktig å kategorisere ut fra det som er hovedinnholdet i kompetansebeskrivelsen.

\section{Læringstråd 1 og 2}

I følge den norske læreplanen skal elevene opparbeide seg naturfaglig kompetanse som i stor grad dreier seg om å formidle kunnskap (Læringstråd 1) og anvende naturvitenskaplige metoder (Læringstråd 2). En årsak til at så mange kompetansebeskrivelser dreier seg om formidling av kunnskap kan være at det i denne planen er et krav om at kompetansemålene skal beskrive kompetanser som må kunne demonstreres gjennom observerbar, ytre atferd (Engelsen \& Karseth, 2007). En måte å demonstrere kognitiv kunnskap gjennom observerbar, ytre atferd, er å formidle denne kunnskapen. Det å kunne formidle begreper, modeller og teorier i naturfag er altså i samsvar med intensjonene i Læringstråd 1.

De fire læringstrådene skal som nevnt over være flettet sammen, altså skal elevenes kompetanse i de ulike områdene utvikles samtidig. For eksempel bør eksperimenter kobles til læring av begreper, modeller og teorier. Samtidig er det i internasjonal forskning en utbredt oppfatning at praktisk arbeid i naturfag ikke har klart å innfri de mange forventningene (Jenkins, 1999). Eksperimentelt arbeid blir ofte gjort som en lite omfattende aktivitet som fokuserer på "direkte rapportering" med lite rom for refleksjon (Tiberghien, Veillard, Le Maréchal, Buty, \& Millar, 2001). Af Geijerstam (2006) finner for eksempel at laboratorierapporten er en dominerende tekstpraksis i naturfaget, men at dialogiske prosesser har fått begrenset plass. I tillegg viser resultater fra PISA+ at det er få faglige elevdialoger (Klette \& Lie, 2006) og at dialogene mellom elev og lærer ofte foregår i et ikke-faglig språk (Ødegaard \& Arnesen, 2006). Dette viser hvilken utfordring det er å integrere eksperimentelt arbeid (Læringstråd 2) og faglig refleksjon (Læringstråd 1). Imidlertid er det slik at ett og samme kompetansemål i den norske læreplanen ofte beskriver kompetanser som både dreier seg om den naturvitenskapelige arbeidsmåte og om det å forstå, bruke eller å tolke naturvitenskapelige forklaringer. For eksempel skal eleven kunne: "[...] gjennomføre forsøk med lys, syn og farger, og beskrive og forklare resultatene." (Fenomener og stoffer, etter 10. trinn). Læreplanen i naturfag har således lyktes relativt godt med å flette sammen formidling av begreper, modeller og teorier (Læringstråd 1) og den naturvitenskapelige arbeidsmåte (Læringstråd 2).

Spørsmålet er videre hvordan selve metoden lykkes med å representere disse læringstrådene. Som nevnt kategoriseres alle kompetansebeskrivelser der formidling av kunnskap står sentralt, men der det ikke eksplisitt kreves samhandling som Formidling (Læringstråd 1). For eksempel skal elevene i den norske læreplanen kunne " [...] presentere resultatene (i sammenheng med værmålinger, red.anm.) med eller uten digitale hjelpemidler" (Fenomener og stoffer, etter 7. trinn). Det er ikke nødvendigvis entydig hvordan denne kompetansebeskrivelsen skal kategoriseres. I følge analyseverktøyet må denne kompetansebeskrivelsen imidlertid kategoriseres som Læringstråd 1, fordi elevene her skal presentere det vi kan definere som modeller i naturvitenskapen.

I tillegg kan det være problematisk å avgjøre forholdet mellom kognitiv kompetanse og psykomotorisk ferdighetskompetanse i læringstrådene. Kompetanse i Læringstråd 1 er i stor grad kognitiv, mens Læringstråd 2 har både en kognitiv og psykomotorisk ferdighetskomponent. Faren er at man lett overser de kognitive komponentene i Læringstråd 2. For eksempel skal elevene i den norske læreplanen kunne: " [...] lage en plan for å undersøke en selvformulert hypotese" (Forskerspiren, 
etter 7. trinn). Denne kompetansebeskrivelsen som kategoriseres som Læringstråd 2, indikerer en kognitiv handling. Dette må en være oppmerksom på i analysen.

\section{Læringstråd 3}

Spørsmålet er så hvordan Læringstråd 3 er ivaretatt og integrert i den norske læreplanen. I avsnittet om formålet med faget blir kjennskap til naturvitenskapelig tenkemåte framhevet som viktig allmennkunnskap:

En viktig del av allmennkunnskapen er å kjenne til at naturvitenskapen er i utvikling, og at forskning og ny kunnskap i naturvitenskap og teknologi har stor betydning for samfunnsutviklingen og for livsmiljøet. (Utdanningsdirektoratet, 2006)

Kompetansemålene i den norske læreplanen i naturfag vektlegger derimot i liten grad at elever skal utvikle forståelse for naturvitenskapens tenkemåte (Læringstråd 3). Intensjonene beskrevet under formålet med faget blir altså ikke fulgt tilfredsstillende opp gjennom forpliktende kompetansemål i læreplanen.

I den grad det legges opp til å trene elevene i den naturvitenskapelige tenkemåte, skjer dette i hovedområdene Forskerspiren og Verdensrommet. Under hovedområdet Verdensrommet, står det at: "[...] eleven skal kunne beskrive [..] naturvitenskapens teorier for hvordan jorda har blitt til" (etter 7. trinn). Det ene kompetansemålet under hovedområdet Forskerspiren etter 7. trinn, som berører den naturvitenskapelige tenkemåte, lyder: "[...] elevene skal kunne forklare hvorfor det er viktig å lage og teste hypoteser ved systematiske observasjoner og forsøk og hvorfor det er viktig å sammenligne resultater". Tilsvarende finnes det tre lignende kompetansebeskrivelser på ungdomstrinnet. Almendingen og Isnes (2005), som begge var sentrale i utviklingen av den norske læreplanen i naturfag, skriver at "Forskerspiren er også et godt utgangspunkt for å gi elevene noe innsikt i hvordan naturvitenskapen utvikler kunnskap". Gjennom Forskerspiren skal altså elevene indirekte kunne få noe forståelse av hvordan naturvitenskapen utvikler kunnskap. Imidlertid vil en slik implisitt tolkning av læreplanen stille store krav til lærerne, spesielt siden forskning viser at barneskolelærere har en utilfredsstillende forståelse av naturvitenskapens tenkemåte (Akerson, Abd-el-Khalick, \& Lederman, 2000). Selv om det å gi elevene mulighet til å arbeide utforskende, slik som hovedområdet Forskerspiren legger opp til, kan styrke elevenes utvikling av epistemologisk forståelse, er det ikke gitt at det skjer automatisk og at det er uproblematisk (Bell \& Linn, 2000). For at elevenes epistemologiske forståelser skal utvikles optimalt må det eksplisitt legges til rette for refleksjon om dette (Khishfe \& Abd-el-Khalick, 2002).

Perspektivet på naturvitenskap som en prosess der teorier er i forandring, betraktes som sidestilt med og like vesentlig som de andre prosessperspektivene. Læringstråd 3, som går ut på å reflektere over hvordan naturvitenskapelig kunnskap utvikles, må i så fall betraktes som like viktig som det vi forbinder med den naturvitenskapelige arbeidsmåte: å stille spørsmål, planlegge undersøkelser, samle inn og representere data, tolke og vurdere resultater.

I analysen fant vi altså at Læringstråd 3 er svakt representert i den norske læreplanen. Analyseverktøyet plasserer kompetansebeskrivelser som tydelig dreier som om den naturvitenskaplige tenkemåte og om hvordan naturvitenskaplig kunnskap dannes i kategorien Naturvitenskaplig tenkemåte (Læringstråd 3). I analysen bør en være oppmerksom på at det er kompetansebeskrivelsens innhold, uavhengig av verbet, som er betydningsfullt for kategoriseringen.

Et annet viktig moment er at kompetansebeskrivelser som beskriver elevens bevissthet om egen læring også bør kategoriseres som Læringstråd 3. Dette er imidlertid ikke relevant i den norske læreplanen, fordi ingen av kompetansebeskrivelsene har et slikt innhold. Dette viser igjen at analyseverktøyet må justeres noe i forhold til materialet som analyseres. 


\section{Læringstråd 4}

Den norske læreplanen vektlegger også i liten grad at elevene skal kunne samhandle i naturfag. Svært få kompetansebeskrivelser sier like eksplisitt som følgende kompetansemål at elevene skal samhandle (Læringstråd 4): "[...] eleven skal kunne planlegge og gjennomføre undersøkelser $i$ noen naturområder $i$ samarbeid med andre" (Mangfoldet i naturen, etter 7. trinn). For øvrig finner vi noen få kompetansebeskrivelser som krever samhandling under hovedområdet Kropp og helse. Formuleringene som dreier seg om samhandling er her av typen å samtale om og å diskutere. Læringstråd 4 favner det aspektet ved å beherske naturfag som går ut på å delta produktivt i samhandling med andre. Med produktiv deltagelse menes deltagelse som fremmer læring. Elevenes deltagelse er altså produktiv ved at de gjør intellektuell fremgang (Engle \& Conant, 2002). Det er mye som tyder på at Læringstråd 4 i liten grad utøves i naturfagundervisningen. Knain (2005b) fant for eksempel at viktige normer for vitenskapelig arbeid, nemlig å skrive slik at andre kan forstå og gjenta forsøket (Læringstråd 4), ble framholdt som viktig av elever, men at dette i liten grad var operasjonalisert i praksis. Dette setter naturfaget inn i en sosial kontekst og henger nøye sammen med et sosialkonstruktivistisk syn på læring (Lemke, 1990). Læringstråd 4 kan ivaretas i klasserommet hvis praksisen preges av et sosialkonstruktivistisk læringssyn og dersom målene som beskriver formidlingskompetanse brukes i en produktiv sammenheng.

I analysen valgte vi å knytte Læringstråd 4 til kategorien Samhandling. For å kunne kategoriseres som Læringstråd 4 må kompetansebeskrivelsen signalisere gruppeprosesser. I den forbindelse er det viktig å nevne at kompetansebeskrivelser der formidling av kunnskap (Læringstråd 1) står sentralt kan anvendes ulikt. Det kan i klasserommet legges vekt på at elevene kun skal prestere individuelt eller at de også skal opptre i samhandling med andre. I analysen er det altså viktig å være oppmerksom på at kompetansebeskrivelsene må indikere samhandling, hvis de skal kategoriseres som Læringstråd 4.

\section{Dybde i naturfaglig kompetanse}

For å utvikle en helhetlig kompetanse i naturfag, må elevene ha en viss dybde i sin faglige forståelse. I læreplanen ville en forvente at kompetansebeskrivelser er dypere og mer komplekse på høyere trinn. Med utgangspunkt i figur 3 har vi foretatt en analyse av utviklingen i kompetansebeskrivelsenes dybde og kompleksitet fra 1. til 10. trinn. Analysen fokuserer også på variasjonen mellom de forskjellige hovedområdene. Elevene skal i følge Læringstråd 1 ikke bare lære separate begreper, modeller og teorier, men de skal også kunne integrere og bruke disse i nye og komplekse sammenhenger. Å kunne anvende kunnskap i nye sammenhenger tilsvarer minimum DOK2-nivå, men da dreier det seg kun om å anvende kunnskap i relativt enkle sammenhenger. Anvendelse av kunnskap i mer komplekse sammenhenger tilsvarer DOK3 eller DOK4. Dette innebærer at Læringstråd 1 ikke blir tilfredsstillende ivaretatt for hovedområdet Kropp og helse, siden det her ikke er noen kompetansebeskrivelser på høyere nivå enn DOK2. Det kan se ut som læreplanen ikke forventer at elevene skal kunne integrere kunnskap om kropp og helse eller kunne anvende helserelaterte spørsmål i nye og komplekse sammenhenger. En kan for eksempel stille spørsmål ved om det ikke er tenkt at elevene skal kunne delta i og forstå diskusjonen om vaksine og liknende debatter. I denne sammenhengen er Jónsdóttir (2009) sine funn interessante. De viser at hennes informanter faktisk skulle ønske at naturfagundervisningen satte dem bedre i stand til å vurdere det de leser og hører, om for eksempel helsefarer. Læringstråd 1 er heller ikke godt nok ivaretatt for hovedområdene Verdensrommet og Fenomener og stoffer, som begge har svært få kompetansebeskrivelser på høyere nivå enn DOK2.

I hovedområdet Forskerspiren er alle fire læringstråder representert. Det ligger i hele Forskerspirens natur at det dreier seg om komplekse sammenhenger, og dette burde komme til utrykk i DOKfordelingen for Forskerspiren. Som forventet er det en progresjon i dette hovedområdet fordi det er flere dype og komplekse kompetansebeskrivelser på høyere trinn enn på lavere trinn. Samtidig kan en spørre hvorfor DOK-4 nivå ikke er representert i Forskerspiren på ungdomstrinnet. 
Videre kan en stille spørsmål om hvordan fordelingen på DOK-nivå bør være innenfor hver årsgruppe og hvordan fordelingen bør utvikle seg fra trinn til trinn. En kan her spørre om fordelingen bør være slik som innenfor hovedområdet Teknologi og design, eller om dette blir for ambisiøst. I formuleringen av kompetansemålene for Teknologi og design har det vært en bevissthet om taksonomisk nivå innenfor hver trinngruppe og en tydelig progresjon fra trinngruppe til trinngruppe (Hansen, 2007). Dersom Teknologi og design skal sette normen, vil konklusjonen være at alle de fem andre hovdeområdene gjennomgående beskriver kompetanser på for lavt DOK-nivå. For enkelte hovedområder mangler også en systematisk progresjon i DOK-nivå gjennom utdanningsløpet.

I den norske læreplanen er kompetansemålene uttrykt i form av verb som eksplisitt sier hva elevene skal kunne demonstrere av kunnskaper og ferdigheter, men dette er ikke nødvendigvis tilfelle for andre læreplaner. Mål som omhandler begreper, modeller og teorier i naturvitenskapen vil i mange planer, som for eksempel den svenske (Skolverket, 2000), være formulert som å ha kunnskaper om, kjenne til og ha innblikk i. For eksempel skal elevene i den svenske læreplanen "ha kunskap om universums, jordens, livets och människans utveckling”. I læreplaner der målformuleringene er av slik generell art, vil det i en analyse være vanskelig å avgjøre DOK-nivået, uten å gjøre en ytterligere tolkning, presisering og nedbrytning av målene.

\section{OPPSUMMERING}

Vi har utviklet en metode for å analysere læreplaner i naturfag. I denne artikkelen har vi undersøkt hvordan dette analyseverktøyet fanger ulike aspekter ved det å beherske naturfag (bredde og dybde) ved å teste det ut på den norske læreplanen i naturfag. Metoden går i korthet ut på at kompetansen som læreplanen beskriver analyseres i to dimensjoner, bredde og dybde. Breddedimensjonen fanger opp både produkt- og prosessaspekter ved det å beherske naturfag, kategorisert på basis av de fire læringstrådene (Duschl m.fl., 2007). Denne dimensjonen i analyseverktøyet skiller mellom tre ulike prosessperspektiver, og gir et mål for hvordan de forskjellige perspektivene blir vektlagt. Dybdedimensjonen fanger opp det taksonomiske nivået og kompleksiteten på den kompetansen som elevene skal demonstrere at de behersker, kategorisert ved hjelp av DOK-nivå (Webb, 1997, 2002).

En forutsetning for metoden er at læreplanen er målstyrt og at målformuleringene er uttrykt i form av verb som eksplisitt uttrykker hva elevene eller studentene skal kunne demonstrere av kompetanse. En styrke ved metoden er at analysen ikke bare gjøres på bakgrunn av verbene, men verbene analyseres i en kontekst (både langs bredde- og dybdedimensjonen). Dette er også en utfordring, fordi det krever at man bruker et visst skjønn. I redegjørelsen for selve metoden og i diskusjonen over har vi forsøkt å vise hvordan metoden nettopp fanger opp produkt- og prosessaspektene (både i bredde og dybde) på en mest mulig konsistent og fullstendig måte.

Analyseverktøyet har avdekket at den norske læreplanen i naturfag bare i noen grad ivaretar de produkt- og prosessperspektivene som anses som viktige for at elevene i skolen skal kunne utvikle en optimal og helhetlig naturfaglig kompetanse. Summen av kompetansebeskrivelser samsvarer bare delvis med internasjonal forsknings anbefalinger om hvordan naturfag som skolefag bør legges opp for at elevene skal få en optimal og helhetlig naturfaglig kompetanse. Når det gjelder kompetansebeskrivelsenes dybde og kompleksitet, er det stor variasjon mellom de ulike hovedområdene. I mange av hovedområdene mangler også en systematisk progresjon gjennom utdanningsløpet.

Metoden er spesifikt testet på den norske læreplanen i naturfag, men vi mener at den har potensial utover dette. De fire breddekategoriene (formidling, naturvitenskapelig arbeidsmåte, naturvitenskapelig tenkemåte og samhandling), er samtidig som de har sterk kobling til de fire læringstrådene, blitt valgt med tanke på testing av den norske læreplanen i naturfag. Med eventuelle justeringer av 
disse breddekategoriene vil metoden kunne brukes til å analysere andre læreplaner i naturfag. Den bør også være egnet til å analysere læreplaner i de enkelte naturvitenskapelige fagdisiplinene i den videregående skole. I tillegg kan den også tenkes overført til ikke-naturvitenskapelige fag dersom breddedimensjonen justeres i samsvar med det som anses som viktige kompetanseområder for den aktuelle fagdisiplinen. Metoden kan også tenkes brukt til å analysere ulike typer vurderingsverktøy og læringsmål i skolers plandokumenter (ukeplaner, årsplaner og lignende).

\section{TAKK}

Dette arbeidet inngår i forskningsprosjektet "Bedre læringsstrategier i realfag", og har blitt støttet økonomisk av Kunnskapsdepartementet.

\section{REFERANSER}

Adam, S. (2004). Using Learning Outcomes: A consideration of the nature, role, application and implications for European education of employing learning outcomes at the local and international levels. [elektronisk utgave]. Sist lest: 19. februar, 2010, fra http://www.scotland.gov. uk/Publications/2004/09/19908/42704.

af Geijerstam, Å. (2006). Att skriva i naturorienterande ämnen i skolan. Acta universitas Upsaliensis. Studia Linguistica Upsaliensia, 3.

Akerson, V. L., Abd-el-Khalick, F., \& Lederman, N. G. (2000). Influence of a reflective explicit activity-based approach on elementary teacher's conceptions of attitudes. Science Education, $72(1), 73-82$.

Almendingen, S. F., \& Isnes, A. (2005). Forskerspiren - tanker og visjoner. Naturfag, 2, 18 - 19.

Amsel, E., \& Brock, S. (1996). The development of ecvidence evaluation skills. Cognitive Development, 11, $523-550$.

Anderson, L. W. (2001). A taxonomy for learning, teaching, and assessing: a revision of Bloom's Taxonomy of educational objectives. New York: Longman.

Bazerman, C. (1988). Shaping written knowledge. Madison, WI: University of Wisconsin Press.

Beeth, M. E., \& Hewson, P. W. (1999). Learning goals in an exemplary science teacher's practice: Cognitive and social factors in. Science Education, 83(6), 738.

Bell, P., \& Linn, M. C. (2000). Beliefs about science: How does science instruction contribute? I B. K. Hofer \& P. R. Pintrich (red.), Personal epistemology: The psychology of beliefs about knowledge and knowing. Mahwa, NJ: Lawrence Erlbaum Associates.

Bloom, B. (1956). Taxonomy of Educational Objectives: The Classification of Educational Goals. New York. : McKay.

Brown, J. S., Collins, A., \& Duguid, P. (1989). Situated Cognition and the Culture of Learning. Educaional Researcher, 18(1), 32 - 42.

Driver, R., Leach, J., Millar, R., \& Scott, P. (1996). Young people's images of science. Buckingham, England: Open University Press.

Duschl, R. A., Schweingruber, H. A., \& Shouse, A. W. (2007). Taking Science to School: Learning and Teaching Science in Grades K-8. Washington D.C.: The National Academies Press.

Echevarria, M. (2003). Anomalies as a catalyst for middle school student's knowledge construction and scientific reasoning during science inquiry. Journal of Educational Psychology, 95, $357-374$.

Engelsen, B. U. (2008). Kunnskapsløftet: sentrale styringssignaler og lokale strategidokumenter. Oslo: Pedagogisk Forskningsinstitutt.

Engelsen, B. U., \& Karseth, B. (2007). Læreplan for Kunnskapsløftet - et endret kunnskapssyn? Norsk Peagogisk Tidsskrift, 5, 404 - 415.

Engle, R. A., \& Conant, F. R. (2002). Guiding Principles for Fostering Productive Disciplinary Engagement: Explaining an Emergent Argument in a Community of Learners Classroom. Cogni- 
tion \& Instruction, 20, 399-483.

Europakommisjonen. (2004). Europe needs more scientists. Brussel.

Europakommisjonen. (2007). Science Education NOW: A Renewed Pedagogy for the Future of Europe. Brussel.

Gobert, J., \& Discenna, J. (1997). The relationship between students' epistemologies and modelbased reasoning. (ERIC Document Reproduction Service No. ED409164). Kalamazoo, MI: Western Michigan University, Department of Science Studies.

Gobert, J., \& Pallant, A. (2001). Making thinking visible: Promoting science learning through modeling and visualizations. Paper presentert på Gordon Research Conference, Mt. Holyoke College, S. Hadley, August 5 - 10.

Hansen, P. J. K. (2007). Teknologi og design - Hva Hvorfor Hvordan: Et fagdidaktisk veiledningshefte. Oslo: Evina og Høgskolen i Oslo, Avdeling for lærerutdanning.

Henessey, M. G. (2002). Metacognitive aspects of students' relflective discourse: implications for intentional conceptual change teaching and learning. I S. G.M. \& P. R. Pintrich (red.), Intentional conceptual change. Mahwah, NJ: Lawrence Erlbaum Associates.

Jenkins, E. W. (1999). Practical work in School Science - some questions to be answered. I J. Leach \& A. C. Paulsen (red.), Practical Work in Science Education (s. 19 - 32). Roskilde og Dordrecht: Roskilde University Press and Kluwer Academic Publishers.

Jónsdóttir, G. (2009). Dubito ergo sum? Ni jenter møter naturfaglig kunnskap. Det psykologiske fakultet, Universitetet i Bergen, Bergen.

Kennedy, D., Hyland, Á., \& Ryan, N. (2007). Writing and Using Learning Outcomes: a Practical Guide. Sist lest 5. februar, 2010, fra http://www.bologna.msmt.cz/files/learning-outcomes. pdf

Khishfe, R., \& Abd-el-Khalick, F. (2002). The influence of explicit and reflective versus implicit inquiry-oriented instruction on sixth graders' views of nature of science. Journal of Research in Science Teaching, 39(7), 551 - 578.

Klahr, D., Fay, A., \& Dunbar, K. (1993). Heuristics for scientific experimentation: A developmental study. Cognitive Psychology, 25, 111 - 146.

Klette, K., \& Lie, S. (2006). Sentrale Funn. Foreløpige resultater fra PISA+ prosjektet [elektronisk versjon]. Foreløpige resultater fra PISA+ prosjektet. Sist lest 19. oktober 2009 fra http://www. pfi.uio.no/forskning/forskningsprosjekter/pisa+/publikasjoner/Sentrale\%20funn.pdf.

Knain, E. (2005a). Definering og valg av kompetanser - DeSeCo. Norsk Pedagogisk Tidsskrift, 1, $45-54$.

Knain, E. (2005b). Identity \& genre literacy in high-school student's experimental reports. International Journal of Science Education, 27(5), 607 - 624.

Kolstø, S. D. (2003). Et allmenndannende naturfag: Fagets betydning for demokratisk deltakelse. I D. Jorde \& B. Bungum (red.), Naturfagdidaktikk: perspektiver, forskning, utvikling (s. 59 - 85). Oslo: Gyldendal akademisk.

Kolstø, S. D. (2009). Vektlegging av lesing i naturfaget. Del 1: Vil den nye norske læreplanen i naturfag øke elevenes lesekompetanse? NorDiNa, 5(1), 61 - 74.

Koslowski, B. (1996). Theory and evidence: The development og scientific reasoning. Cambridge: MA: MIT Press.

Kuhn, D., Garcia-Mila, M., Zohar, A., \& Andersen, C. (1995). Strategies of knowledge acquisition. Monographs of the Society for Research in Child Development, Serial No. 245, 60(4).

Latour, B. (1990). Drawing things Together. I M. Lynch \& S. Woolgar (red.), Representation in Scientific Practice (s. 19 - 68). Massachusetts: MIT Press.

Lave, J., \& Wenger, E. (1991). Situated learning: legitimate peripheral participation. Cambridge: Cambridge University Press.

Lederman, N. G., Abd-el-Khalick, F., Bell, R. L., \& Schwartz, R. S. (2002). Views of nature of science questionaire: Towards valid and meaningful assessment of learner's conceptions of the nature of science. Journal of Research in Science Teaching, 39(6), 497 - 521.

Lee, O., \& Fradd, S. H. (1996). International patterns of linguistically diverse students and teachers: Insights for promoting science learning. Linguistics and Education: An International 
Research Journal, 8, 269 - 297.

Lee, O., \& Fradd, S. H. (1998). Science for all, including students from non-English language backgrounds. Educaional Researcher, 27(3), 12 - 21.

Lehrer, R., Schauble, L., Strom, D., \& Pligge, M. (2001). Similarity of form and substance: Modeling material kind. I D. Klahr \& S. Carver (red.), Cognition and instruction: 25 years of progress (s. 39 - 74). Mahwah, NJ: Lawrence Erlbaum Associates.

Lemke, J. L. (1990). Talking science: language, learning, and values. Norwood, N.J.: Ablex.

Lucas, D., Broderick, N., Lehrer, R., \& Bohanan, R. (2005). Making the grounds of scientific inquiry visible in the classroom. ScienceScope, 29(3), 39 - 42.

Martin, J. R. (1993). Literacy in Science: Learning to handle text as technology. I M. A. K. Halliday \& J. R. Martin (red.), Writing science: Literacy and discursive power (s. 166 - 220). Pittsburgh PA: University of Pittsburgh Press.

McComas, W. F., \& Olson, J. K. (1998). The nature of science in international science education standards documents. I W. F. McComas (red.), The nature of science in science education: Rationales and strategies (s. 41 - 52). Dordrecht: Kluwer.

Mortimer, E. F., \& Scott, P. (2003). Meaning making in secondary science classrooms. Buckingham: Open University Press.

Osborne, J. F., Collins, S., Ratcliffe, M., Millar, R., \& Duschl, R. A. (2003). What "Ideas-aboutscience" should be taught in school science? A Delphi study of the expert community. Journal of Research in Science Teaching, 40(7), 692 - 720.

Penner, D., \& Klahr, D. (1996). The interaction of domain-specific knowledge and domain-general discovery strategies: A study within sinking objects. Child Development, 67, 2709 - 2727.

Rosebery, A. S., Warren, B., \& Conant, F. R. (1992). Appropriating scientific discourse: Findings from language minority classrooms. The Journal of the Learning Sciences, 2(1), 61 - 94.

Rychen, D. S., \& Salganic, L. H. (2001). Defining and Selecrting Key Competencies. Seattle og Göttingen: Hogrefe \& Huber.

Sandoval, W. A. (2005). Understanding student's practical epistemologies and their influence on learning through inquiry. Science Education, 89, 634 - 656.

Sandoval, W. A., \& Reiser, B. J. (2004). Explanation-driven inquiry: integrating conceptual and epistemic scaffolds for scientific inquiry. Science Education, 88, 345 - 372.

Schauble, L. (1990). Belief revision in children: The role of prior knowledge and strategies for generating evidence. Journal of Experimental Child Psychology, 49(1), 102 - 119.

Schauble, L. (1996). The development of scientific reasoning in knowledge-rich contexts. Developmental Psychology, 32(1), 102 - 119.

Sjøberg, S. (2009). Naturfag som allmenndannelse: en kritisk fagdidaktikk. Oslo: Gyldendal akademisk.

Skolverket. (2000). Kursplan för Naturorienterande ämnen. Sist lest 4. juni 2010, fra http://www. skolverket.se/sb/d/2386/a/16138/func/kursplan/id/3878/titleId/NO1010\%20-\%20Naturorienterande $\% 20 \% \mathrm{E} 4 \mathrm{mnen}$

Songer, N. B., \& Linn, M. C. (1991). How do students' view of the scientific enterprise influence knowledge integration? Journal of Research in Science Teaching, 28(9), 761 - 784.

St.meld. nr. 30. (2003-2004). Kultur for loering. Oslo: Utdannings- og forskningsdepartementet.

Tiberghien, A., Veillard, L., Le Maréchal, J.-F., Buty, C., \& Millar, R. (2001). An Analysis of Labwork Tasks Used in Science Teaching at Upper Secondary School and University Levels in Several European Countries. Science Education, 85, 483 - 508.

Toth, E., Suthers, D., \& Lesgold, A. (2002). Mapping to know: The effects of evidence maps and reflective assessment on scientific inquiry skills. Science Education, 86(2), 264 - 286.

Utdanningsdirektoratet. (2006). Læreplan i naturfag. . Sist lest 10. februar, 2010, fra http://www. utdanningsdirektoratet.no/grep/Lareplan/?laereplanid $=117461$

Webb, N. L. (1997). Criteria for alignment of expectations and assessments in mathematics and science education. Council of Chief State School Officers and National Institute for Science Education Research Monograph. No. 6. Madison: University of Wisconsin, Wisconsin Center 
for Education Research.

Webb, N. L. (2002). Depth of knowledge levels for four content areas. Sist lest 2009.10.19, fra http://www.bullittschools.org/tis/curriculumMap/DOK/DOK_ContentAreas.pdf

Zimmerman, C., Raghavan, K., \& Sartoris, M. L. (2003). The impact of the MARS curriculum on student's ability to coordinate theory and evidence. International Journal of Science Education, 25, 1247 - 1271.

Ødegaard, M., \& Arnesen, N. E. (2006). Video Tales of Teaching in Norwegian Science Classrooms. Paper presentert på The 9th Nordic Research Symposium on Science Education, Reykjavik. 